\title{
PENGARUH PARTISIPASI ANGGARAN TERHADAP KINERJA MANAJERIAL MELALUI KOMITMEN ORGANISASI DAN MOTIVASI SEBAGAI VARIABEL MODERATING (Studi Empiris Pada Perusahaan Manufaktur di Jakarta dan Tangerang)
}

\author{
Aditiya Christianto Gunawan dan Linda Santioso \\ Fakultas Ekonomi Universitas Tarumanagara Jakarta \\ Email: linda_santioso@gmail.com
}

\begin{abstract}
The purpose of this research is to analyst the influence of participation in composing budget toward managerial performance, whether through organization commitment and motivation as moderating variable. The inconsistency situations between results of the prior research, about the influence of budget participation on managerial performance become a motivation of this study. Data used in this study is obtained from ideas or perceptions of managers who filled and gave the questionnaires back to the researcher. From 200 questionnaires which distributed to managers on manufacturing companies which stated at Jakarta and Tangerang. 122 (61\%) questionnaires were sent back, and 19 questionnaires can't used because of the incomplete answer, for then analyzed with moderate regression analysis in SPSS 19.00. The result of these study proving that the value of directly influence between budget participation toward managerial performance. Commitment as variable moderating succeed given influence, but not with the motivation. However, the researcher can make conclusion that organization commitment as moderating variable is influence the managers participation in compose budget toward their performance on managerial activities, but not with the motivation as moderating variable.
\end{abstract}

Key words: budget participation, organization commitment, motivation and managerial performance.

\begin{abstract}
Abstrak: Penelitian ini bertujuan untuk memperoleh bukti empiris mengenai ada atau tidaknya pengaruh partisipasi penyusunan anggaran terhadap kinerja manajerial pada perusahaan manufaktur dengan komitmen organisasi dan motivasi sebagai variable moderating. Adanya ketidakkonsistenan hasil dari penelitian-penelitian sebelumnya menjadi motivasi peneliti untuk dilakukannya kembali penelitian ini. Data yang diperoleh dikumpulkan dengan cara menyebarkan kuesioner kepada para manajer perusahaan dan tim penyusun anggaran. Dari 200 kuesioner yang disebarkan kepada perusahaan manufaktur yang berdomisili di daerah Jakarta dan Tangerang, hanya 122 kuesioner yang dapat diperoleh kembali dan 19 kuesioner tidak dapat digunakan karena data yang diisi tidak lengkap. Penelitian ini dilakukan dengan menggunakan bantuan SPSS (Statistical Program For Social Science) versi 19.00. Metode statistik yang digunakan untuk menguji hipotesis yaitu model Simple Regression, Multiple Regression dan Moderated Regression Analysis. Sebelum melakukan pengujian hipotesis dilakukan pengujian kualitas data, dan asumsi klasik. Hasil penelitian menunjukkan partisipasi anggaran berpengaruh terhadap kinerja manajerial, dan interaksi antara partisipasi
\end{abstract}


anggaran dengan komitmen organisasi juga memiliki pengaruh terhadap kinerja manajerial, sedangkan motivasi tidak berhasil memoderasi pengaruh partisipasi anggaran terhadap kinerja manajerial. Penelitian selanjutnya disarankan agar menambah sektor perusahaan yang menjadi sampel penelitian, serta menambahkan variabel-variabel lainnya yang mempengaruhi kinerja manajerial.

Kata kunci: partisipasi anggaran, komitmen organisasi, motivasi, kinerja manajerial

\section{PENDAHULUAN}

Pertumbuhan ekonomi dan implikasi globalisasi membuat semua jenis bidang usaha bersaing dengan ketat. Bagi perusahaan hal itu merupakan suatu tantangan agar dapat bertahan dan berkembang dalam lingkungan bisnis yang dapat dikatakan labil. Dalam persaingan bisnis ini, manajemen perusahaan harus memiliki sebuah alat untuk membantu mereka dalam merencanakan dan mengalokasikan sumber daya yang tersedia seefisien mungkin. Salah satu alat yang membantu manajemen adalah anggaran. Proses penyusunan anggaran pasti melibatkan peran para manajer dalam perusahaan.

Rosidi (2000) dalam Yunita (2005), menjelaskan bahwa penyusunan anggaran dapat dilakukan dengan pendekatan top-down dan bottom-up. Pendekatan top-down dapat menimbulkan dysfunctional behavior karena manajer tingkat bawah hanya menjalankan apa yang telah digariskan anggaran, sedangkan pendekatan bottom-up memungkinkan terjadinya negosiasi diantara para manajer untuk mencapai tujuan organisasi. Dengan pendekatan ini berarti para bawahan diikutsertakan atau ikut berpartisipasi untuk memberi ide atau masukan terhadap anggaran yang nantinya akan diimplementasikan.

Partisipasi penyusunan anggaran merupakan pendekatan yang secara umum dapat meningkatkan kinerja yang pada akhirnya dapat meningkatkan efektivitas organisasi. Partisipasi merupakan alat untuk mencapai tujuan, partisipasi juga sebagai alat untuk mengintegrasikan kebutuhan individu dan organisasi. Sehingga partisipasi dapat diartikan sebagai berbagi pengaruh, pendelegasian prosedur-prosedur, keterlibatan dalam pengambilan keputusan dan suatu pemberdayaan. Untuk mendukung pengaruh antara partisipasi penganggaran dan kinerja manajerial, diperlukan pendekatan kontijensi dengan mengevaluasi faktor-faktor yang menyebabkan partisipasi penganggaran menjadi lebih efektif. Faktor-faktor yang ditambahkan dalam penelitian ini adalah komitmen organisasi dan motivasi kerja.

Komitmen organisasi merupakan keinginan yang kuat untuk tetap menjadi anggota organisasi dengan mengerahkan segala upaya atas nama organisasinya dengan suatu keyakinan penerimaan nilai dan tujuan dari organisasi. Dengan komitmen yang tinggi dari manajer dan para bawahannya, artinya manajer dan karyawan perusahaan memiliki motivasi kuat untuk semakin memajukan perusahaan tempat mereka bekerja. Salah satu cara untuk dapat meningkatkan kinerja perusahaannya yaitu dengan menyusun anggaran perusahaan seefektif mungkin.

Motivasi merupakan derajat sampai dimana seorang individu ingin dan berusaha melaksanakan suatu tugas atau pekerjaan dengan sebaik mungkin dan kesediaan untuk mengeluarkan tingkat upaya yang tinggi ke arah tujuan organisasi. Dikaitkan dengan penyusunan anggaran, maka dalam prosesnya mungkin akan lebih efektif dalam kondisi karyawan yang memiliki motivasi yang tinggi, begitu juga sebaliknya (Ghozali, 2005). 
Penelitian ini merupakan replikasi dari penelitian-penelitian sebelumnya. Perbedaan utama penelitian ini dengan penelitian sebelumnya adalah penggabungan dari variabel moderatnya, yaitu komitmen organisasi dan motivasi. Dalam penelitian J. Sumarno (2005) hanya menguji pengaruh komitmen organisasi sebagai variabel moderating terhadap hubungan partisipasi anggaran dan kinerja manajerial, sedangkan Sukardi (2004) hanya menguji motivasi sebagai variabel moderatingnya. Sedangkan dalam penelitian ini selain menguji pengaruh partisipasi anggaran terhadap kinerja manajerial, juga menambahkan 2 variabel moderat yang di ambil dari penelitian J.Sumarno dan Sukardi.

Dengan demikian, penelitian ini berusaha menguji: (1) apakah partisipasi anggaran berpengaruh terhadap kinerja manajerial, (2) apakah partisipasi anggaran berpengaruh terhadap kinerja manajerial dengan komitmen organisasi sebagai variabel moderating, (3) apakah partisipasi anggaran berpengaruh terhadap kinerja manajerial dengan motivasi sebagai variabel moderating. Kerangka penelitian ini tampak pada gambar 1.

Untuk menguji pengaruh antar variabel tersebut digunakan kuesioner survey yang dikirim kepada manajer dan tim penyusun anggaran pada perusahaan manufaktur yang terdapat di wilayah Jakarta dan Tangerang. Selanjutnya data yang terkumpul akan dilakukan analisis model persamaan regresi untuk menguji hipotesis-hipotesis yang dibuat. Pengujian hipotesis dilakukan dengan menggunakan program SPSS 19.00.

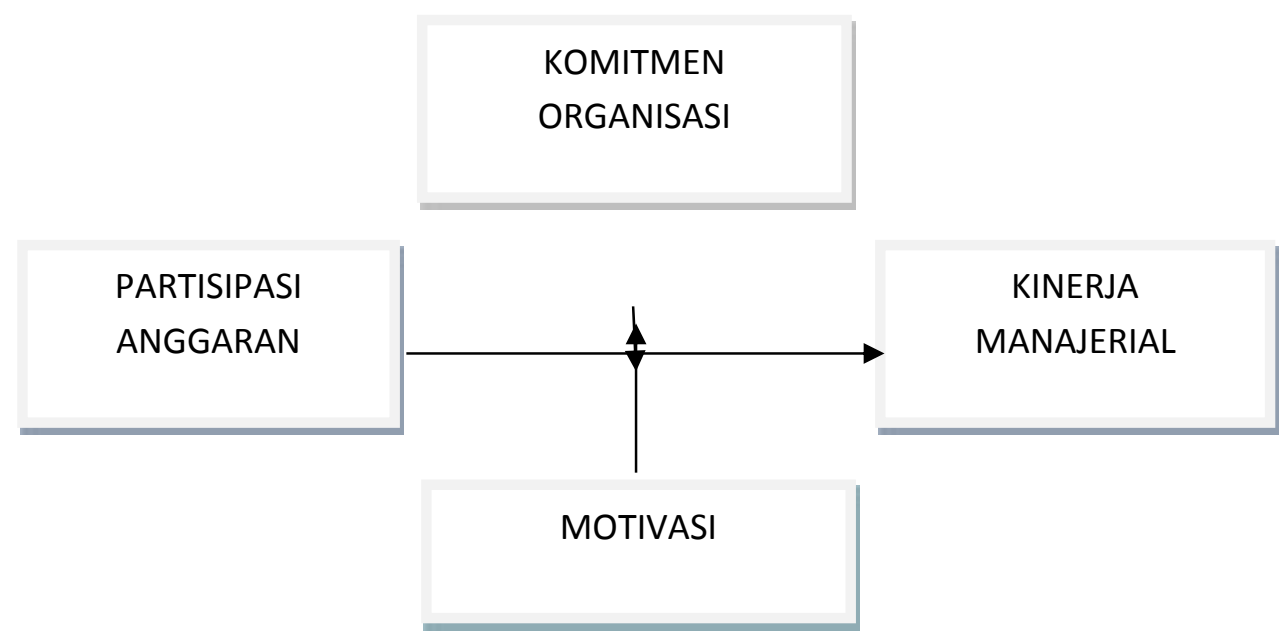

Gambar 1. Kerangka penelitian

\section{KAJIAN TEORI}

Partisipasi Anggaran dan Kinerja Manajerial. Anggaran merupakan pernyataan mengenai apa yang diharapkan dalam periode tertentu pada masa yang akan datang. Sebagai rencana keuangan, anggaran berfungsi sebagai dasar untuk menilai kinerja (Lewin,1970 dalam Sukardi, 2004). Anggaran juga tidak hanya sebagai rencana keuangan untuk alokasi biaya dan pendapatan dalam suatu perusahaan, tetapi juga merupakan alat bagi manajer tingkat atas untuk mengendalikan, mengkoordinasikan, mengkomunikasikan, dan mengevaluasi kinerja dan memotivasi bawahannya. 
Govindarajan dalam Sukardi (2004) menjelaskan bahwa pertisipasi anggaran memiliki pengaruh positif terhadap kinerja manajerial. Kecenderungan yang lebih besar dari bawahan untuk menerima target anggaran bilamana mereka beranggapan bahwa mereka turut serta memegang kendali, daripada bila anggaran tersebut ditetapkan secara sepihak.

Menurut Hansen \& Mowen (2008: 357), partisipasi anggaran adalah:

Rather than imposing budgets on subordinate managers participative budgetings allows subordinate managers considerable say in how the budgets are established. Typically, overall objectives are communicated to the manager, who helps develops a budget that will accomplish these objectives

Menurut Kenis (1979) dalam Rinarti (2007), mengartikan partisipasi penyusunan anggaran sebagai berikut:

Partisipasi penyusunan anggaran adalah sebuah keterlibatan manajer dalam menyusun anggaran pada pusat pertanggungjawaban manajer yang bersangkutan, yang mengarah kepada seberapa besar tingkat keterlibatan tersebut dalam menyusun anggaran serta pelaksanaannya untuk menggapai anggaran.

Partisipasi dalam penyusunan anggaran memiliki peran yang sangat penting. Partisipasi dari bawahan dalam proses penyusunan anggaran secara tidak langsung akan mempengaruhi diri mereka, karena mungkin mereka dianggap memiliki kemampuan, sehingga dapat memotivasi para bawahan tersebut untuk bekerja lebih baik lagi yang berdampak pada meningkatnya kinerja perusahaan.

Schiff dan Lewin (1970) dalam Sardjito (2008), mengemukakan bahwa anggaran yang telah disusun memiliki dua peranan. Pertama, anggaran berperan sebagai perencanaan, yaitu bahwa anggaran tersebut berisi tentang ringkasan rencana-rencana keuangan organisasi di masa yang akan datang. Kedua, anggaran berperan sebagai kriteria kinerja, yaitu anggaran dipakai sebagai sistem pengendalian untuk mengukur kinerja manajerial.

Mangkunegara (2006:67) kinerja manajerial diartikan sebagai "hasil kerja secara kualitas dan kuantitas yang dicapai oleh seseorang pegawai dalam melaksanakan tugasnya sesuai dengan tanggung jawab yang diberikan kepadanya". Sedangkan Hasibuan (2001:34) menyebutkan kinerja manajerial adalah "suatu hasil kerja yang dicapai seseorang dalam melaksanakan tugas tugas yang dibebankan kepadanya yang didasarkan atas kecakapan, pengalaman dan kesungguhan serta waktu".

Penilaian kinerja adalah penentuan secara periodik efektifitas operasional suatu organisasi, bagian organisasi, dan karyawannya berdasarkan sasaran standar dan kriteria yang telah ditetapkan sebelumnya, Mulyadi (1993:419) dalam Sukardi (2004). Dalam hubungannya dengan karyawan, yang dimaksud dengan kinerja manajerial adalah kinerja para individu anggota organisasi dalam kegiatan-kegiatan manajerial seperti; perencanaan, investigasi, koordinasi, supervisi, dan representasi.

Kinerja manajerial yang diperoleh manajer merupakan salah satu faktor yang dapat dipakai untuk meningkatkan efektifitas organisasi. Hampir seluruh organisasi pada dasarnya dijalankan oleh manusia, maka penilaian kinerja sesungguhnya merupakan penilaian atas perilaku manusia dalam melaksanakan peran yang mereka mainkan didalam organisasi. 
Hasil penilaian kinerja dapat digunakan untuk mengidentifikasi kelemahan anggota organisasi dan untuk mengantisipasi keahlian dan keterampilan yang dituntut oleh pekerjaan, agar dapat memberikan respon yang memadai terhadap perubahan lingkungan organisasi dimasa yang akan datang. Rahayu (1999) dalam Rinarti (2007), mendefinisikan kinerja manajerial sebagai "kegiatan yang didasarkan pada fungsi-fungsi manajemen yang meliputi: perencanaan, investigasi, koordinasi, evaluasi, supervisi, pmilihan staf, negosiasi, dan perwakilan."

Kinerja manajerial yang diperoleh manajer merupakan salah satu faktor yang dapat dipakai untuk meningkatkan efektifitas organisasi. Partisipasi bawahan dalam menyusun anggaran dan peran anggaran sebagai pengukur kinerja memiliki kaitan yang cukup erat (Riyadi, 1999) dalam Rinarti (2007).

Beberapa peneliti telah menguji hubungan dan pengaruh partisipasi anggaran dan kinerja manajerial, namun hasilnya menunjukkan perbedaan. Rinarti (2007) menunjukkan terdapat pengaruh antara partisipasi penyusunan anggaran terhadap kinerja manajerial secara signifikan. Penelitian yang dilakukan Ghozali (2005) menunjukkan partisipasi anggaran berpengaruh positif dan signifikan terhadap kinerja manajerial. Sementara itu penelitian Yuniarti (2008) menunjukkan tidak terdapat pengaruh signifikan dari partisipasi anggaran terhadap kinerja manajerial. Berdasarkan temuan para peneliti diatas, maka dapat digambarkan sebagai berikut.

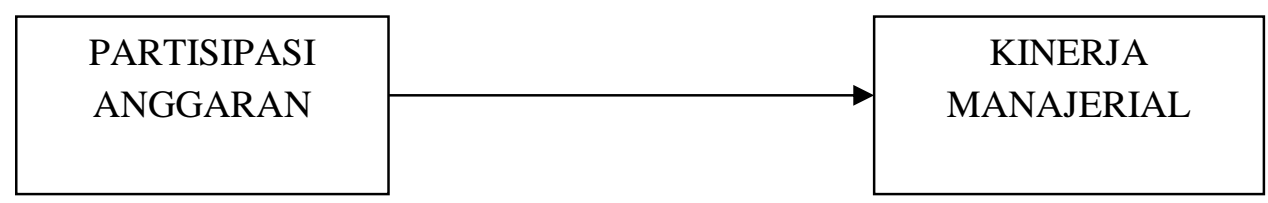

Gambar 2. Pengaruh Partisipasi Anggaran terhadap Kinerja Manajerial

Berdasarkan gambar 2 diatas, peneliti mengajukan hipotesis sebagai berikut.

Ha1: Terdapat pengaruh partisipasi penyusunan anggaran terhadap kinerja manajerial.

Komtimen Organisasi. Komitmen organisasi merupakan suatu keinginan yang kuat untuk tetap menjadi anggota dari sebuah organisasi. Komitmen ini ditunjukan dengan adanya loyalitas dari para pekerja secara terus menerus kepada organisasi demi keberhasilan dan kesejahteraan organisasinya. Manajer yang memiliki komitmen tinggi, akan memiliki pandangan positif dan lebih berusaha untuk berbuat lebih baik lagi untuk kepentingan perusahaannya.

Komitmen organisasi dapat tumbuh disebabkan karena individu memiliki ikatan emosi terhadap organisasi. Ikatan emosi tersebut meliputi; dukungan moral dan menerima nilai yang ada dalam organisasi serta tekad dari dalam diri untuk mengabdi pada organisasi.

Menurut Ivancevich dan Matteson (2006:234), komitmen diartikan sebagai "perasaan identifikasi, keterlibatan, dan kesetiaan yang diekspresikan oleh karyawan terhadap perusahaan." Syariffudin (2001:35) mengartikan komitmen organisasi yaitu "sikap karyawan untuk tetap berada dalam organisasi dan terlibat dalam upaya-upaya mencapai misi, nilai-nilai dan tujuan organisasi". Lebih lanjut dijelaskan, bahwa komitmen merupakan suatu bentuk loyalitas yang lebih konkret yang dapat dilihat dari 
sejauh mana karyawan mencurahkan perhatian, gagasan, dan tanggung jawab dalam upaya mencapai tujuan organisasi.

Komitmen yang tinggi secara tidak langsung akan mempengaruhi kinerja perusahaan. "Orang yang memiliki komitmen cenderung tidak berhenti dan mau menerima pekerjaan lain, lebih lanjut lagi, seorang karyawan yang berkomitmen tinggi memiliki persepsi bahwa nilai dan tujuan dari individu memberi kontribusi pada sasaran organisasi" (Mathis dan Jackson, 2004:154).

Berdasarkan pemahaman diatas, maka dapat digambarkan sebagai berikut:

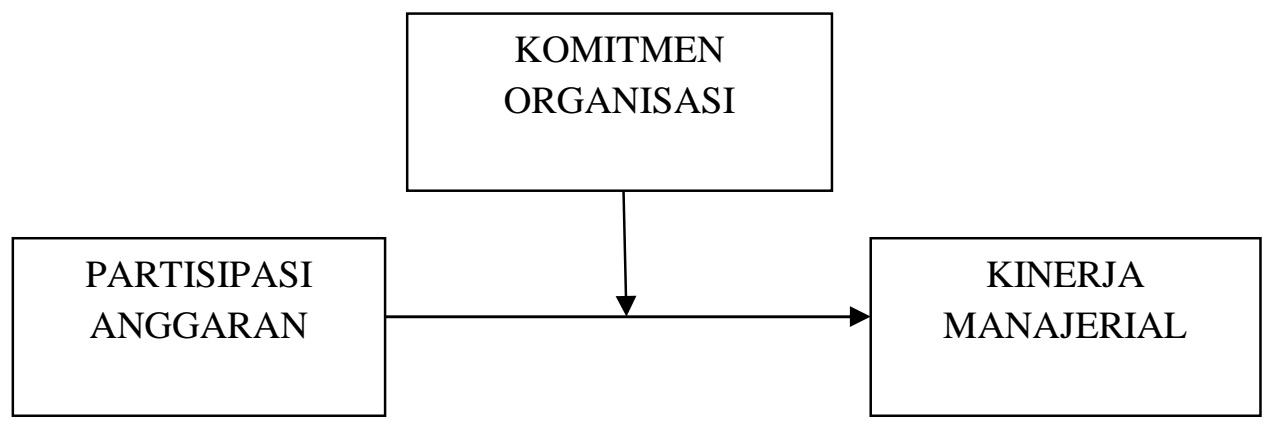

Gambar 3. Pengaruh Partisipasi Anggaran Terhadap Kinerja Manajerial Dengan

Komitmen Organisasi Sebagai Variabel Moderating

Berdasarkan gambar 3 diatas, peneliti mengajukan hipotesis sebagai berikut.

Ha2: Terdapat pengaruh partisipasi penyusunan anggaran terhadap kinerja manajerial dengan komitmen organisasi sebagai variabel moderating.

Motivasi. Robbins (2008:58) mendefinisikan motivasi sebagai "proses yang menjelaskan intensitas, arah dan ketekunan usaha untuk mencapai suatu tujuan." Siagian (2002:113) mengemukakan motivasi sebagai "daya dorong bagi seseorang untuk memberikan kontribusi yang sebesar mungkin demi keberhasilan organisasi mencapai tujuannya."

Solihin (2009:152) memberi pengertian mengenai motivasi sebagai:

Kekuatan psikologis yang akan menentukan arah dari perilaku seseorang (direction of a person's behavior), tingkat upaya (level of effort) dari seseorang dan tingkat ketegaran (level of persistence) pada saat orang itu dihadapkan pada berbagai rintangan.

Motivasi merupakan derajat sampai dimana seorang individu ingin dan berusaha melaksanakan suatu tugas atau pekerjaan dengan sebaik mungkin dan kesediaan untuk mengeluarkan tingkat upaya yang lebih tinggi ke arah tujuan organisasi. Dikaitkan dengan penyusunan anggaran, maka dalam prosesnya mungkin akan lebih efektif dalam kondisi karyawan yang memiliki motivasi yang tinggi, dan begitu juga sebaliknya (Ghozali, 2005). Vroom (1994) dalam Nasir (2008) menyatakan bahwa motivasi mengarah kepada sebuah keputusan mengenai berapa banyak usaha yang akan dikeluarkan dalam suatu situasi tugas tertentu. Pilihan ini didasarkan pada harapan melalui dua tahap, yang pertama yaitu motivasi dipengaruhi oleh harapan individu. Kemudian motivasi juga dipengaruhi oleh peluang yang dirasakan oleh karyawan untuk mendapatkan berbagai hasil sebagai akibat dari tercapainya tujuan prestasinya. Penelitian Sukardi (2004) tentang hubungan antara partisipasi anggaran dengan kinerja manajerial melalui peran motivasi kerja dan 
kultur organisasi sebagai variabel moderating yang dilakukan terhadap badan usaha koperasi di Jawa Tengah, menunjukkan hasil bahwa terdapat pengaruh dari partisipasi anggaran terhadap kinerja manajerial, sedangkan interaksi antara partisipasi anggaran dengan motivasi kerja tidak berhasil menunjukkan adanya pengaruh yang signifikan terhadap kinerja manajerial.

Berdasarkan pemahaman di atas maka dapat digambarkan sebagai berikut.

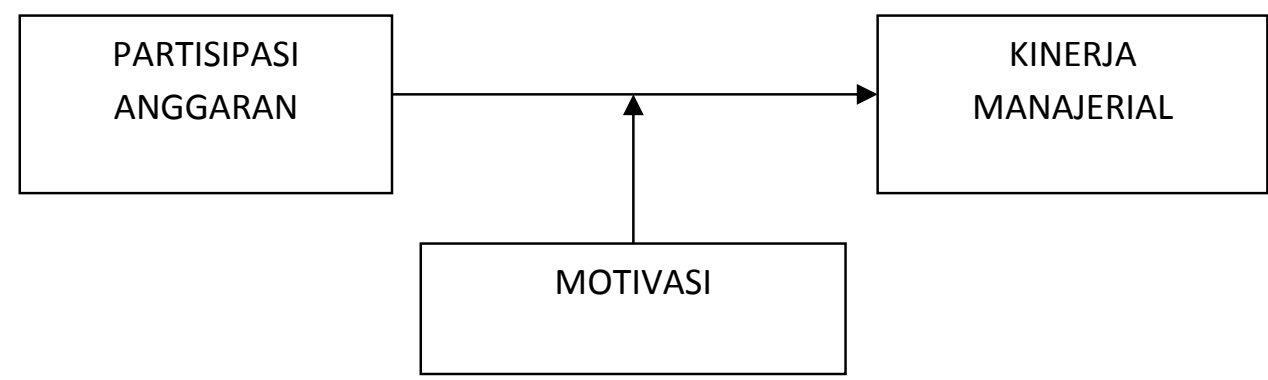

Gambar 4. Pengaruh Partisipasi Anggaran Terhadap Kinerja Manajerial Dengan Motivasi Sebagai Variabel Moderating

Berdasarkan gambar 4 diatas, peneliti mengajukan hipotesis sebagai berikut.

Ha3: Terdapat pengaruh partisipasi penyusunan anggaran terhadap kinerja manajerial dengan motivasi sebagai variabel moderating.

\section{METODE}

Unit observasi yang digunakan dalam penelitian ini adalah perusahaan manufaktur yang terdapat di daerah Tangerang dan Jakarta. Sampel yang dipilih sebagai responden adalah para manajer perusahaan dan tim penyusun anggaran. Kriteria ini dipilih karena dimaksudkan telah memiliki pengalaman dalam menyusun anggaran yang menjadi tanggung jawabnya.

Kuesioner yang dibagikan berjumlah 200 buah, dan sebanyak 122 buah yang dapat ditarik kembali. Setelah dilakukan pengeditan data dan persiapan untuk pengolahan data, sebanyak 19 buah tidak dapat digunakan karena pengisian kuesioner yang tidak lengkap dan kosong. Sehingga kuesioner yang dapat digunakan sebagai data dalam penelitian ini berjumlah 103 buah.

Moderat Regression Analysis digunakan untuk menentukan pengaruh interaksi antara variabel independen dan variabel moderat, yaitu antara partisipasi anggaran dan komitmen organisasi, partisipasi anggaran dan motivasi terhadap kinerja manajerial. Berdasarkan pendekatan ini, dapat dibuat persamaan regresi untuk menjawab hipotesis dalam penelitian ini. Persamaa regresi untuk masing-masing hipotesis dapat ditunjukkan sebagai berikut:

$$
\begin{aligned}
& Y=\beta_{0}+\beta_{1} X_{1}+\varepsilon \\
& Y=\beta_{0}+\beta_{1} X_{1}+\beta_{2} X_{2}+\varepsilon \\
& Y=\beta_{0}+\beta_{1} X_{1}+\beta_{2} X_{2}+\beta_{3} X_{1} X_{2}+\varepsilon \\
& Y=\beta_{0}+\beta_{1} X_{1}+\beta_{3} X_{3}+\varepsilon
\end{aligned}
$$




$$
Y=\beta_{0}+\beta_{1} X_{1}+\beta_{3} X_{3}+\beta_{4} X_{1} X_{3}+\varepsilon
$$

Keterangan: $Y=$ Kinerja Manajerial; $\quad \beta_{0}=$ Konstanta; $X_{1}=$ Partisipasi Anggaran; $X_{2}=$ Komitmen Organisasi; $\mathrm{X}_{3}=$ Motivasi; $\mathrm{X}_{1} \mathrm{X}_{2}=$ Interaksi antara Partisipasi anggaran dan Komitmen organisasi; $\mathrm{X}_{1} \mathrm{X}_{3}=$ Interaksi antara Partisipasi anggaran dan Motivasi

Persamaan (1) menggambarkan pengaruh yang diberikan oleh partisipasi anggaran terhadap kinerja manajerial sebagai variabel dependennya. Persamaan ini menggunakan regresi linear sederhana karena hanya untuk mengetahui pengaruh variabel independen terhadap variabel dependen. Persamaan (2) dan (3) terdapat 2 rumus berbeda, rumus pertama terdapat penjumlahan antara $\mathrm{X} 1-\mathrm{X} 2$ dan $\mathrm{X} 1-\mathrm{X} 3$, hal ini untuk mengetahui pengaruh komitmen organisasi maupun motivasi sebelum berinteraksi dengan partisipasi anggaran. Setelah itu baru ditambahkan rumus perkalian yaitu X1.X2 dan X1.X3, di mana arti dari perkalian ini adalah interaksi antara variabel independen dengan variabel moderatnya, dimana pada persamaan (2) akan terlihat interaksi antara partisipasi anggaran dengan komitmen organisasi dan persamaan (3) yaitu interaksi antara partisipasi anggaran dengan motivasi. Interaksi ini selanjutnya akan diuji, apakah dengan adanya interaksi ini akan mempengaruhi kinerja manajerial.

\section{Operasionalisasi Vaiabel}

a. Variabel Independen. Variabel independen yang digunakan dalam penelitian ini adalah partisipasi anggaran. Yang dimaksud dengan partisipasi anggaran adalah tingkat keterlibatan dan pengaruh para individu dalam proses penyusunan anggaran (Mia, 1998) dalam J.Sumarno (2005). Pengukuran variabel menggunakan instrument berupa kuesioner yang diadopsi dari Milani (1975) dalam Rinarti (2007). Pengukuran ini dilakukan dengan menggunakan skala likert dengan rentang 1 sampai 7, skala rendah (poin 1) menunjukkan partisipasi tinggi dan skala tinggi (poin 7) menunjukkan partisipasi rendah.

b. Variabel Dependen. Mahoney et. al. (1965) dalam Rinarti (2007) mendefinisikan kinerja manajerial didasarkan pada fungsi-fungsi manajemen yang meliputi: perencanaan, investigasi, koordinasi, evaluasi, supervisi, pemilihan staf, negosiasi, dan perwakilan. Variabel ini diukur dengan menggunakan kuesioner yang dikembangkan oleh Mahoney et. al. (1965) dalam Rinarti (2007). Pengukuran ini dilakukan dengan skala 1 sampai 9, mencakup skala 1 (kinerja sangat dibawah ratarata) sampai skala 9 (kinerja sangat diatas rata-rata).

c. Variabel Moderating. Variabel moderating yang digunakan dalam penelitian ini ada 2 yaitu komitmen organisasi dan motivasi kerja. Komitmen organisasi adalah dorongan dari dalam individu untuk melakukan sesuatu agar dapat menunjang keberhasilan organisasi sesuai dengan tujuan yang ditetapkan dan lebih mengutamakan kepentingan organisasi. Pengukuran variabel ini dilakukan dengan daftar pertanyaan (kuesioner) yang dikembangkan oleh Mowday et. al. (1979) dalam J.Sumarno (2005). Pengukuran dilakukan dengan menggunakan skala likert dengan rentang 1 sampai 7. Nilai skala menunjukkan nilai skor jawaban setiap butir pertanyaan. Motivasi didefinisikan sampai dimana seseorang memiliki kemauan dan berusaha melaksanakan suatu tugas dengan baik (Ghozali, 2005). Orang-orang termotivasi untuk menilai kegiatannya jika mereka merasa bahwa konsekuensi dari kegiatannya menguntungkan, kemudian mereka merasa bahwa akan mencapai tujuan yang mereka 
inginkan. Pengukuran motivasi ini menggunakan daftar pertanyaan yang dikembangkan oleh Yogi (2008), dengan menggunakan skala likert 5 poin, dimana skala 1 menunjukkan motivasi rendah, dan skala 5 menunjukkan motivasi kerja tinggi.

\section{HASIL DAN PEMBAHASAN}

Tabel 1. Pengujian Statistik Deskriptif

\begin{tabular}{|c|c|c|c|c|c|}
\hline \multicolumn{6}{|c|}{ Descriptive Statistics } \\
\hline & $\mathrm{N}$ & Minimum & Maximum & Mean & Std. Deviation \\
\hline ParAng & 103 & 1,0000 & 6,6667 & 2,639159 & ,8893270 \\
\hline KinManaj & 103 & 3,1111 & 7,7778 & 6,188781 & 9404742 \\
\hline KomOrg & 103 & 3,0000 & 6,7778 & 5,281553 & ,7583658 \\
\hline Mtvsi & 103 & 2,7000 & 4,9000 & 4,219417 & ,4207972 \\
\hline Valid N (listwise) & 103 & & & & \\
\hline
\end{tabular}

\section{Pengujian Instrumen Penelitian}

a. Uji Validitas Data

Tabel 2. Uji validitas

\begin{tabular}{llcll}
\hline Dimensi & Item & Pearson Corelation & Sig. & Status \\
Partisipasi & Pertanyaan 1 & 0,871 & 0,000 & Valid \\
Penyusunan & Pertanyaan 2 & 0,850 & 0,000 & Valid \\
Anggaran & Pertanyaan 3 & 0,826 & 0,000 & Valid \\
& Pertanyaan 4 & 0,863 & 0,000 & Valid \\
& Pertanyaan 5 & 0,830 & 0,000 & Valid \\
Kinerja & Pertanyaan 6 & 0,878 & 0,000 & Valid \\
Manajerial & Pertanyaan 1 & 0,788 & 0,000 & Valid \\
& Pertanyaan 2 & 0,781 & 0,000 & Valid \\
& Pertanyaan 3 & 0,683 & 0,000 & Valid \\
& Pertanyaan 4 & 0,739 & 0,000 & Valid \\
& Pertanyaan 5 & 0,767 & 0,000 & Valid \\
& Pertanyaan 6 & 0,807 & 0,000 & Valid \\
& Pertanyaan 7 & 0,839 & 0,000 & Valid \\
& Pertanyaan 8 & 0,767 & 0,000 & Valid \\
Komitmen & Pertanyaan 9 & 0,811 & 0,000 & Valid \\
Organisasi & & & & \\
& Pertanyaan 1 & 0,584 & 0,000 & Valid \\
& Pertanyaan 2 & 0,691 & 0,000 & Valid \\
& Pertanyaan 3 & 0,522 & 0,000 & Valid \\
& Pertanyaan 4 & 0,800 & 0,000 & Valid \\
& Pertanyaan 5 & 0,787 & 0,000 & Valid \\
& Pertanyaan 6 & 0,802 & 0,000 & Valid \\
& Pertanyaan 7 & 0,744 & 0,000 & Valid \\
& Pertanyaan 8 & 0,780 & 0,000 & Valid \\
& Pertanyaan 9 & 0,690 & 0,000 & Valid
\end{tabular}


Gunawan dan Santioso: Pengaruh Partisipasi Anggaran Terhadap Kinerja Manajerial...

\begin{tabular}{llcll}
\hline Dimensi & Item & Pearson Corelation & Sig. & Status \\
\hline Motivasi & Pertanyaan 1 & 0,573 & 0,000 & Valid \\
& Pertanyaan 2 & 0,599 & 0,000 & Valid \\
& Pertanyaan 3 & 0,534 & 0,000 & Valid \\
& Pertanyaan 4 & 0,665 & 0,000 & Valid \\
& Pertanyaan 5 & 0,540 & 0,000 & Valid \\
& Pertanyaan 6 & 0,695 & 0,000 & Valid \\
& Pertanyaan 7 & 0,646 & 0,000 & Valid \\
& Pertanyaan 8 & 0,526 & 0,000 & Valid \\
& Pertanyaan 9 & 0,678 & 0,000 & Valid \\
& Pertanyaan 10 & 0,686 & 0,000 & Valid \\
\hline
\end{tabular}

Berdasarkan Tabel 2 diketahui signifikansi dari masing - masing pertanyaan untuk variabel partisipasi anggaran, kinerja manajerial, komitmen organisasi dan motivasi lebih kecil dari 0,05 (5\%), yang berarti pertanyaan - pertanyaan tersebut valid.

b. Uji Reliabilitas

Tabel 3. Uji Reliabilitas

\begin{tabular}{lrc}
\hline \multicolumn{1}{c}{ Dimensi } & Crobach Alpha & N of Items \\
\hline Partisipasi Anggaran & 0,925 & 6 \\
Kinerja Manajerial & 0,916 & 9 \\
Komitmen organisasi & 0,875 & 9 \\
Motivasi & 0,816 & 10 \\
\hline
\end{tabular}

Dari hasil perhitungan reliabilitas diperoleh nilai Cronbach Alpha untuk semua variabel berturut-turut untuk variabel Partisipasi Anggaran, Kinerja Manajerial, Komitmen Organisasi, dan Motivasi kerja adalah 0,925; 0,916; 0,875; 0,816. Semua nilai Cronbach Alpha mendekati 1 , berarti butir-butir pertanyaan penyusun variabel-variabel tersebut reliabel untuk digunakan.

\section{Pengujian Asumsi Klasik}

Tabel 4. Uji Normalitas

\begin{tabular}{llr}
\hline \multicolumn{2}{c}{ One-Sample Kolmogorov-Smirnov Test } & Unstandardized Residual \\
\hline $\mathrm{N}$ & & 103 \\
Normal Parameters ${ }^{\mathrm{a}, \mathrm{b}}$ & Mean &, 0000000 \\
& Std. Deviation &, 90995235 \\
Most Extreme & Absolute &, 120 \\
Differences & Positive &, 068 \\
& Negative &,- 120 \\
Kolmogorov-Smirnov Z & & 1,214 \\
Asymp. Sig. (2-tailed) &, 105 \\
\hline a. Test distribution is Normal. \\
b. Calculated from data.
\end{tabular}

Jurnal Akuntansi/Volume XIX, No. 01, Januari 2015: 144-159 
Berdasarkan uji normalitas dengan menggunakan metode Kolmogorov Smirnov seperti pada tabel diatas dapat disimpulkan bahwa data berdistribusi normal. Hal ini terlihat dari nilai Asymp. Sig. (2-tailed) 0,105>0,05.

a. Uji Heteroskedastisitas

Tabel 5. Hasil Pengujian Heteroskedastisitas

Coefficients $^{\mathrm{a}}$

\begin{tabular}{|c|c|c|c|c|c|c|}
\hline \multirow[b]{2}{*}{ Model } & & \multicolumn{2}{|c|}{ Unstandardized Coefficients } & $\begin{array}{l}\text { Standardized } \\
\text { Coefficients }\end{array}$ & \multirow[b]{2}{*}{$\mathrm{t}$} & \multirow[b]{2}{*}{ Sig. } \\
\hline & & $\mathrm{B}$ & Std. Error & Beta & & \\
\hline 1 & (Constant) & 445 & 187 & & 2,377 & ,019 \\
\hline & ParAng & ,087 & ,067 & ,128 & 1,301 & 196 \\
\hline
\end{tabular}

Uji Heteroskedastisitas dalam peneniltian ini menggunakan uji glejser. Data dikatakan tidak heteroskedastisitas apabila signifikasinya lebih besar dari 0,05 atau 5\%. Dari tabel diatas, dapat dilihat bahwa signifikasi dari partisipasi anggaran 0,196>0,05.

b. Uji Multikolinieritas

Tabel 6. Hasil Pengujian Multikolinieritas

\begin{tabular}{|c|c|c|c|c|c|c|c|}
\hline \multirow[b]{3}{*}{ Model } & \multicolumn{5}{|c|}{ Coefficients $^{\mathrm{a}}$} & \multirow{2}{*}{\multicolumn{2}{|c|}{$\begin{array}{l}\text { Collinearity } \\
\text { Statistics }\end{array}$}} \\
\hline & \multicolumn{2}{|c|}{$\begin{array}{l}\text { Unstandardized } \\
\text { Coefficients }\end{array}$} & \multirow{2}{*}{$\begin{array}{c}\begin{array}{c}\text { Standardized } \\
\text { Coefficients }\end{array} \\
\text { Beta }\end{array}$} & \multirow[b]{2}{*}{$\mathrm{t}$} & \multirow[b]{2}{*}{ Sig. } & & \\
\hline & $\mathrm{B}$ & Std. Error & & & & Tolerance & VIF \\
\hline 1 (Constant) & 4,855 & 1,051 & & 4,619 & ,000 & & \\
\hline ParAng &,- 222 & ,098 &,- 210 & $-2,265$ &, 026 & ,921 & 1,086 \\
\hline KomOrg &, 509 &, 116 & ,411 & 4,393 &, 000 & ,905 & 1,105 \\
\hline Mtvsi &,- 183 & 214 &,- 082 &,- 852 & ,396 & 861 & 1,162 \\
\hline
\end{tabular}

a. Dependent Variable: KinManaj

Deteksi adanya multikolinearitas dengan melihat nilai Variance Inflation Factor (VIF). Apabila VIF lebih besar dari lima maka variabel tersebut mempunyai masalah multikolinearitas sedangkan jika nilai VIF kurang dari lima variabel tersebut tidak mempunyai masalah multikolinearitas. Pada Tabel 6 dapat dilihat bahwa nilai VIF partisipasi anggaran, komitmen organisasi, dan motivasi secara berturut-turut sebesar 1,086; 1,105; dan 1,162 yang artinya seluruh variabel memiliki nilai $\mathrm{VIF}<5$.

\section{Pengujian Hipotesis. Analisis Regresi Satu (Ha1)}

Hipotesis 1 dirumuskan sebagai berikut.

Ha1: Terdapat pengaruh partisipasi penyusunan anggaran terhadap kinerja manajerial.

$\begin{array}{llllll}\text { Variabel } & \text { Coeficient } & \text { Nilai } & \text { Standar Eror } & \mathrm{t} & \text { sig. }\end{array}$




\begin{tabular}{llrcrr}
\hline \multicolumn{1}{c}{$\mathrm{Y}=\beta_{0}+\beta_{1} \mathrm{X}_{1}+\varepsilon$} & & & & & \\
Konstanta & $\beta_{0}$ & 6,894 & 0,283 & 24,326 & 0 \\
Partisipasi & & & & & \\
Anggaran & $\beta_{1}$ & $-0,267$ & 0,102 & $-2,625$ & 0,01 \\
$\mathrm{r}=0,253$ & $\mathrm{R}^{2}=0,064$ & $\mathrm{n}=103$ & $\mathrm{~F}=6,889, \operatorname{sig} 0,010<0,05$ & & \\
\hline
\end{tabular}

Berdasarkan tabel di atas maka dapat diperoleh persamaan regresi linear sederhana sebagai berikut: $\mathrm{Y}=6,894-0,267 \mathrm{X}_{1}$, yang artinya konstanta 6,894 menunjukkan nilai kinerja manajerial pada intersep, yaitu pada saat semua variabel bebas yang digunakan memiliki nilai $0, \beta 1=-0,267$ menyatakan bahwa setiap penambahan satu satuan variabel partisipasi anggaran akan mengurangi nilai kinerja manajerial sebesar -0,267.

Hasil uji secara parsial t hitung masing-masing variabel dapat dijelaskan, yaitu partisipasi anggaran (X1), diperoleh t hitung $=-2,625$ dengan signifikansi t $0,010<0,05$; hal ini menunjukkan bahwa faktor partisipasi anggaran berpengaruh signifikan terhadap kinerja manajerial.

Pada Tabel tersebut terlihat nilai $\mathrm{F}$ sebesar 6,889 dengan signifikansi $\mathrm{F}$ sebesar $0,010<0,05$; hal ini menunjukkan bahwa partisipasi anggaran berpengaruh signifikan terhadap kinerja manajerial. Nilai koefisien determinasi yang diperoleh adalah sebesar 0,064, artinya kinerja manajerial dapat diterangkan oleh faktor partisipasi anggaran sebesar $6,4 \%$, sedangkan sisanya dipengaruhi oleh variabel lain diluar variabel bebas.

Analisis Regresi Dua (Ha2). Hipotesis 2 dirumuskan sebagai berikut.

Ha2: Terdapat pengaruh partisipasi penyusunan anggaran terhadap kinerja manajerial dengan komitmen organisasi sebagai variabel moderating.

\begin{tabular}{|c|c|c|c|c|c|c|}
\hline & \multirow[b]{2}{*}{ Variabel } & \multicolumn{5}{|c|}{ Standar } \\
\hline & & Coeficient & Nilai & Eror & $\mathrm{t}$ & sig. \\
\hline \multirow{12}{*}{$r=0,460$} & $Y=\beta_{0}+\beta_{1} X_{1}+\beta_{2} X_{2}+\varepsilon$ & & & & & \\
\hline & Konstanta & $\beta_{0}$ & 4,173 & 0,681 & 6,131 & 0,000 \\
\hline & Partisipasi Anggaran & $\beta_{1}$ & $-0,202$ & 0,095 & $-2,127$ & 0,036 \\
\hline & Komitmen Organisasi & $\beta_{2}$ & 0,483 & 0,112 & 4,329 & 0,000 \\
\hline & $\mathrm{R}^{2}=0,212$ & $\mathrm{n}=103$ & \multicolumn{2}{|c|}{$\begin{array}{l}\mathrm{F}=13,420, \mathrm{sig} \\
0,000<0,05\end{array}$} & & \\
\hline & $\beta_{0}+\beta_{1} X_{1}+\beta_{2} X_{2}+\beta_{3} X_{1} X_{2}$ & & & & & \\
\hline & $+\varepsilon$ & & & & & \\
\hline & Konstanta & $\beta_{0}$ & $-0,947$ & 1,605 & $-0,59$ & 0,556 \\
\hline & Partisipasi Anggaran & $\beta_{1}$ & 1,744 & 0,566 & 3,084 & 0,003 \\
\hline & Komitmen Organisasi & $\beta_{2}$ & 1,476 & 0,304 & 4,856 & 0,000 \\
\hline & Interaksi 1 & $\beta_{3}$ & $-0,381$ & 0,109 & $-3,486$ & 0,001 \\
\hline & $\mathrm{R}^{2}=0,298$ & $\mathrm{n}=103$ & \multicolumn{2}{|c|}{$\mathrm{F}=13,995$, sig } & & \\
\hline
\end{tabular}


Pengaruh adanya interaksi antara partisipasi anggaran dan komitmen organisasi adalah signifikan yang ditunjukkan dengan perubahan nilai $\mathrm{R}^{2}$ yaitu sebesar 0,086 , dari sebelum ada interaksi $=0,212$ dan setelah interaksi menjadi $=0,298$. Nilai statistik $F=$ 13,420 sebelum ada interaksi antara partisipasi anggaran dengan komitmen organisasi, pada tingkat signifikansi $0,000<0,05$ dan sesudah ada interaksi nilai $\mathrm{F}$ menjadi 13,995 pada tingkat signifikansi $0,000<0,05$. Hal ini menunjukkan liniearitas regresi dan model regresi signifikan.

Komitmen organisasi (KomOrg), diperoleh $\mathrm{t}$ hitung $=4,856$ dengan signifikansi $\mathrm{t}$ $0,000<0,05$. Hal ini menunjukkan bahwa faktor komitmen organisasi berpengaruh signifikan terhadap kinerja manajerial.

Variabel moderating (interaksi1), diperoleh $\mathrm{t}$ hitung $=-3,486$ dengan signifikansi $\mathrm{t}$ $0,001<0,05$. Hal ini menunjukkan bahwa faktor komitmen organisasi sebagai variabel moderating berpengaruh signifikan terhadap kinerja manajerial.

Dari hasil diatas dapat disimpulkan bahwa faktor partisipasi anggaran berpengaruh signifikan terhadap kinerja manajerial melalui faktor komitmen organisasi sebagai variabel moderating.

Pada Tabel di muka terlihat nilai $\mathrm{F}$ sebesar 13,995 dengan signifikansi $\mathrm{F}$ sebesar $0,000<0,05$; hal ini menunjukkan bahwa partisipasi anggaran dan komitmen organisasi sebagai variabel moderating secara bersama-sama berpengaruh signifikan terhadap kinerja manajerial. Nilai koefisien determinasi yang diperoleh adalah sebesar 0,298, artinya kinerja manajerial dapat diterangkan oleh faktor partisipasi anggaran dan komitmen organisasi sebagai variabel moderating sebesar 29,8\%. Selanjutnya sebesar 70,2\% dipengaruhi oleh variabel lain diluar variabel bebas yang digunakan.

Analisis Regresi Tiga (Ha3). Hipotesis 3 dirumuskan sebagai berikut.

Ha3: Terdapat pengaruh partisipasi penyusunan anggaran terhadap kinerja manajerial dengan motivasi sebagai variabel moderating.

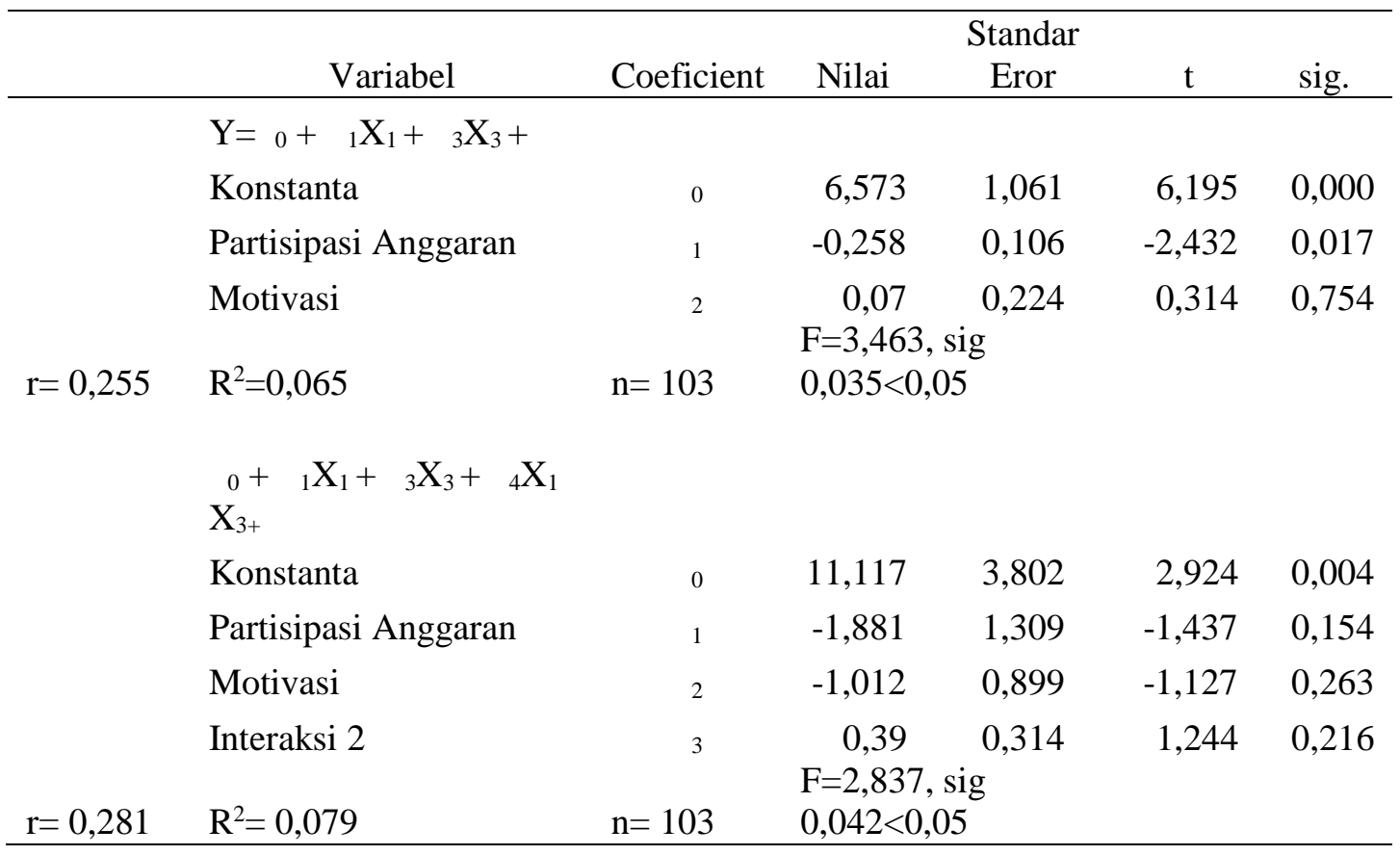


Nilai statistik $\mathrm{F}=3,463$ sebelum ada interaksi antara partisipasi anggaran dengan motivasi, pada tingkat signifikansi $0,035<0,05$ dan sesudah ada interaksi nilai $\mathrm{F}$ menjadi 2,837 pada tingkat signifikansi $0,042<0,05$. Hal ini menunjukkan liniearitas regresi dan model regresi signifikan. Berdasarkan tabel diatas, hasil uji secara parsial t hitung masingmasing variabel dapat diuraikan sebagai berikut; Motivasi (Mtvsi), diperoleh t hitung = 1,127 dengan signifikansi t 0,263>0,05. Hal ini menunjukkan bahwa faktor motivasi tidak berpengaruh signifikan terhadap kinerja manajerial

Variabel moderating (interaksi2), diperoleh t hitung $=1,244$ dengan signifikansi $t$ $0,216>0,05$. Hal ini menunjukkan bahwa faktor motivasi sebagai variabel moderating tidak berpengaruh signifikan terhadap kinerja manajerial. Dari hasil diatas dapat disimpulkan bahwa faktor partisipasi anggaran tidak berpengaruh signifikan terhadap kinerja manajerial melalui faktor motivasi sebagai variabel moderating. Nilai koefisien determinasi yang diperoleh adalah sebesar 0,079, artinya kinerja manajerial dapat diterangkan oleh faktor partisipasi anggaran dan motivasi sebagai variabel moderating sebesar $7,9 \%$. Selanjutnya sebesar $92,1 \%$ dipengaruhi oleh variabel lain diluar variabel bebas yang digunakan.

\section{PENUTUP}

Simpulan. Hasil pengujian hipotesis pertama, menunjukan korelasi negatif dan signifikan antara variabel partisipasi anggaran dengan kinerja manajerial. Hal ini menunjukan bahwa hipotesis tidak ditolak yang artinya terdapat pengaruh partisipasi anggaran terhadap kinerja manajerial. Penelitian ini sejalan dengan penelitian Rinarti (2007) yang menunjukkan bahwa partisipasi anggaran berpengaruh terhadap kinerja manajerial secara signifikan. Hasil ini juga sejalan dengan penelitian Ghozali (2005) yang menyebutkan partisipasi dalam penyusunan anggaran berpengaruh secara signifikan terhadap kinerja manajerial. Namun, hasil ini tidak sejalan dengan penelitian Yuniarti (2008) yang menunjukkan pengaruh partisipasi penyusunan anggaran terhadap kinerja manajerial tidak signifikan.

Hasil pengujian hipotesis kedua, menunjukkan bahwa variabel komitmen organisasi memenuhi kriteria sebagai variabel moderat, yang berarti bahwa komitmen organisasi memoderasi pengaruh partisipasi anggaran terhadap kinerja manajerial. Penelitian ini sejalan dengan penelitian Tangkau (2009) yang menunjukkan bahwa interaksi antara partisipasi anggaran dengan komitmen organisasi berpengaruh signifikan terhadap kinerja manajerial. Hasil ini juga sejalan dengan penelitian Sardjito (2008) yang menunjukkan terdapat pengaruh antara variabel komitmen organisasi dalam memoderasi partisipasi penyusunan anggaran dengan kinerja manajerial. Namun hasil penelitian ini tidak sejalan dengan hasil penelitian Yuniarti (2008) yang menunjukkan interaksi antara partisipasi anggaran dan komitmen organisasi terhadap kinerja manajerial memiliki signifikansi diatas 0,05 , artinya komitmen organisasi tidak berhasil memoderasi pengaruh partisipasi anggaran terhadap kinerja manajerial.

Hasil pengujian hipotesis ketiga, menunjukkan bahwa variabel motivasi tidak memenuhi kriteria sebagai variabel moderat, yang berarti bahwa motivasi tidak memoderasi pengaruh partisipasi anggaran terhadap senjangan anggaran. Penelitian ini sejalan dengan penelitian Sukardi (2004) yang menunjukkan motivasi sebagai variabel 
moderating tidak berpengaruh signifikan terhadap pengaruh partisipasi anggaran dan kinerja manajerial.

Berdasarkan hasil penelitian diperoleh koefisien determinasi variabel independent (partisipasi anggaran) terhadap variabel dependent (kinerja manajerial) sebesar 0,064. Koefisien ini mempunyai arti besarnya variasi variabel dependent (kinerja manajerial) yang dapat dijelaskan oleh variabel independent (partisipasi anggaran) adalah sebesar $6,4 \%$ dan sisanya sebesar 93,6\% dijelaskan oleh variasi variabel lain.

Penelitian ini memiliki keterbatasan yaitu jumlah sampel yang diambil dalam penelitian ini terbatas, penelitian ini dilakukan hanya terhadap perusahaan manufaktur yang terdapat di daerah Tangerang dan Jakarta, sehingga hasil penelitian ini dapat berbeda apabila dilakukan terhadap jenis perusahaan lainnya, dan penelitian ini hanya menggunakan 2 (dua) variabel moderat, yaitu komitmen organisasi dan motivasi.

Saran. Untuk penelitian selanjutnya disarankan agar dapat memanfaatkan waktu sebaik baiknya untuk penyebaran dan pengumpulan kuesioner. Jika data yang diperoleh dapat diperbanyak lagi, maka akan dapat meningkatkan kualitas hasil penelitian. Ruang lingkup dari penelitian ini juga dapat diperluas lagi, baik terhadap perusahaan dagang atau lembaga keuangan, dan penelitian selanjutnya juga dapat menambah variabel moderat yang lain yang mungkin juga dapat memoderasi pengaruh variabel independent dengan variabel dependent.

\section{DAFTAR RUJUKAN}

Ghozali Imam. (2011) Aplikasi Analisis Multivariate dengan Program IBMM SPSS $19^{\text {th }}$ Edition. Semarang: UNDIP

Ghozali, Imam dan Kusnasriyantiyusfaningrum. (2005) Analisis Pengaruh Partisipasi Anggaran Terhadap Kinerja Manajerial melalui Komitmen Tujuan Anggaran sebagai Variabel Intervening. Simposium Nasional Akuntansi VIII. September. hal 656-666.

Hansen \& Mowen. (2008) Cost Manajement. USA: Thomson South Western.

Hasibuan, Maluyu S. P. (2001) Manajemen Sumber Daya Manusia. Jakarta: PT Bumi Askara

Ivancevich \& Matteson. (2006) Organizational Behaviour And Management. Singapore: The Mc Graw- Hill Companies.

Mangkunegara, Anwar Prabu. (2006). Manajemen Sumber Daya Manusia. Bandung: Remaja Rosdakarya.

Mathis \& Jackson. (2004) Manajemen Sumber Daya Manusia $4^{\text {th }}$ edition. Jakarta: Salemba Empat.

Nasir, Mohamad. (2008) Pengaruh Partisipasi dalam Penyusunan Anggaran terhadap Kinerja Manajerial dan Motivasi sebagai Variabel Intervening.

Rinarti, Deasy dan Muindro Renyowijaya. (2007) "Pengaruh Ketidakpastian Lingkungan dan Budaya Organisasi Terhadap Partisipasi Anggaran dan Kinerja Manajerial". Jurnal Bisnis \& Akuntansi. Vol.9, (2) Agustus 2007, hal 124-135

Robbins, P Stephen. (2008) Perilaku Organisasi. Jakarta: PT Index Kelompok Gramedia

Sardjito, Bambang dan Osmad Muthaher. (2008) "Pengaruh Partisipasi Anggaran Terhadap Kinerja Aparat Pemerintah Daerah; Budaya dan Komitmen Organisasi 
sebagai Variabel Moderating”. Jurnal Ekonomi \& Bisnis. Vol.2, (1). Maret 2008, hal 37-49.

Siagian, Sondang. (2002) Manajemen Motivasi. Jakarta: Rineka Cipta.

Solihin, Ismail. (2009) Pengantar Manajemen. Jakarta: Erlangga.

Sukardi. (2004) Hubungan Antara Anggaran Partisipatif dengan Kinerja Manajerial; Peran Motivasi Kerja dan Kultur Organisasi sebagai Variabel Moderating. Jurnal Maksi. Vol.4, (2) Januari 2004, hal 82-89.

Sumarno, J. (2005) Pengaruh Komitmen Organisasi dan Gaya Kepemimpinan Terhadap Hubungan Antara Partisipasi Anggaran dan Kinerja Manajerial. Simposium Nasional Akuntansi VIII. September. hal 586-616.

Syariffudin, Alwi. (2001) Manajemen Sumber Daya Manusia: Startegi Keunggulan Komperatif. Yogyakarta: Andi Offset.

Tangkau, Jaqueline. (2009) "Analisis Pengaruh Komitmen Organisasi dan Partisipasi Anggaran Terhadap Kinerja Manajerial dan Senjangan Anggaran”. Jurnal Formas. Vol.2, (4) Juni 2009, hal 295-302.

Yuniarti, Evi dan Fadila Margasaty. (2008) "Pengaruh Komitmen Organisasi dan Gaya Kepemimpinan Terhadap Hubungan Antara Partisipasi Anggaran dan Kinerja Manajerial". Jurnal Ilmiah Esai. Vol 2, (1) Januari 2008, hal 25-35.

Yunita. (2005) "Pengaruh Partisipasi Penyusunan Anggaran Terhadap Kinerja Manajerial: Komitmen Organisasi dan Kecukupan Anggaran sebeagai Vaiabel Kontijensi". Media Riset Akuntansi, Auditing, dan Informasi. Vol.9, (3) Juni 2005, hal 57-73. 